http://kitaibelia.unideb.hu/

ISSN 2064-4507 (Online) • ISSN 1219-9672 (Print)

(C) 2015, Department of Botany, University of Debrecen, Hungary

20 (2): 259-267.; 2015

DOI: $10.17542 /$ kit.20.259

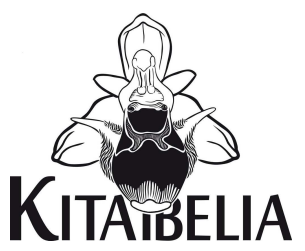

\title{
Kárpáti, erdélyi, dácikus és pannon endemikus fajok a Szilágyság flórájában
}

\author{
NEGREAN Gavril ${ }^{1}$, KARÁCSONYI Károly ${ }^{2}$ \& SZATMARI Paul-Marian ${ }^{3}$ \\ (1) Ro-77531 Bucureşti, Bd. Iuliu Maniu 55.; negrean-gavril@yahoo.com \\ (2) D-88212 Ravensburg, Allgäustr. 2 . \\ (3) Botanical Garden "Vasile Fati”, Ro-455200 Jibou
}

\section{Carpathian, Transylvanian, Dacian and Pannonian elements in the flora of Sălaj region (NW Romania)}

\begin{abstract}
This paper gives an account of biogeographically interesting plant species of the traditional ethnographic region Sălaj (in Hungarian: "Szilágyság”, NW Romania). The flora of the region, which is situated between the Transylvanian Basin and the eastern part of the Great Hungarian Plain, contains, besides the prevailing European species, a significant percentage of plant species from different biogeographic regions. Among these we noticed the continental species of eastern origin, as well as southern Sub-Mediterranean species broadly distributed in this area. A significant number of other interesting species is further represented by the endemic and sub-endemic Carpathian (Aconitum moldavicum Hacq., Symphytum cordatum Waldst. \& Kit.), Transylvanian (Cephalaria radiata Griseb. \& Schenk, Onosma pseudoarenaria Schur subsp. pseudoarenaria), Dacian (Helleborus purpurascens Waldst. \& Kit., Phyteuma tetramerum Schur) and Pannonian (Centaurea sadleriana Janka), species, which occur in very different habitats.
\end{abstract}

Keywords: biogeography, chorology, endemics, flora of Romania, Sălaj (Szilágy) region

Összefoglalás - Az Erdélyi-medence és az alföldi pannon flóratartomány között elterülő romániai Szilágyság növénytakarójában az európai fajok mellett, a különböző földrajzi eredetű flóraelemek százalékos aránya igen magas. Ezek közül kiemeljük a keleti eredetű kontinentális, valamint a déli szubmediterrán jellegűek itteni széleskörű elterjedését. Jelentős számmal vannak képviselve az alább elemzett kárpáti (Aconitum moldavicum Hacq., Symphytum cordatum Waldst. \& Kit.), erdélyi (Cephalaria radiata Griseb. \& Schenk, Onosma pseudoarenaria Schur subsp. pseudoarenaria), dácikus (Helleborus purpurascens Waldst. \& Kit., Phyteuma tetramerum Schur) és pannon (Centaurea sadleriana Janka), endemikus valamint szubendemikus fajok is, amelyek igen különböző jellegű termőhelyeken jelentkeznek.

Kulcsszavak: biogeográfia, endemizmusok, korológia, Románia flórája, Szilágyság

Rezumat - Elemente carpatice, transilvane, dacice şi pannonice în flora Sălajului (România). În covorul vegetal al Sălajului din România, cuprins între Bazinul Transilvaniei şi regiunea floristică pannonică Alföld, în afară de speciile europene, procentul altor elemente de origini diferite, este destul de ridicat. Dintre acestea remarcăm răspândirea largă a elementelor de origine estică continentale, ca şi a celor sudice submediteraneene. Sunt reprezentate în număr mare elementele endemice şi subendemice carpatice (Aconitum moldavicum Hacq., Symphytum cordatum Waldst. \& Kit.), transilvane (Cephalaria radiata Griseb. \& Schenk, Onosma pseudoarenaria Schur subsp. pseudoarenaria), dacice (Helleborus purpurascens Waldst. \& Kit., Phyteuma tetramerum Schur) şi pannonice (Centaurea sadleriana Janka), prezente în habitate foarte diverse.

Cuvinte-cheie: biogeografie, corologie, endemite, flora României, Sălaj 


\section{Bevezetés}

A Szilágyság (Sălaj, România) földrajzi helyzetéből adódóan kapcsolatot teremt az Erdélyimedence (Depresiunea Transilvaniei) és az ettől nyugatra fekvő alföldi régiót (Câmpia de Vest) elfoglaló pannon flóratartomány között. Az átmeneti jelleg hűen tükröződik e kontaktterület növénytakarójában. Itt huzódik több fás növény [Quercus pubescens Willd., Quercus frainetto Ten., Sorbus danubialis (Jáv.) Kárpáti] északi elterjedési peremének egy szakasza. Ugyanakkor több keleti eredetű (kontinentális) faj expanziós útvonala rajzolódik ki e területen. Uralkodó felszíni formája a dombvidék, amelyet a Nyugati-Szigethegység (Muntii Apuseni) két északi nyúlványa, a Meszes és a Réz-hegység (Munţii Meseş - Plopiş) tarkít.

A szórványos florisztikai kutatások már a XIX. században elkezdődtek (FEICHTINGER 1875, FREYN 1877), amelyek a múlt század folyamán korlátolt területeken folytatódtak (BALÁZS 1941, UjVÁRosi 1947, ColdEA 1971, NYÁRÁdY et al. 1976, SZABó 1983, KARÁCSONYI 2011). Az általunk 1970-es években itt megkezdett botanikai gyűjtőutakat (Karácsonyi, 1971. 04. 10., Negrean, 1973. 09. 02.) az utóbbi években kiterjesztettük Szilágy megye teljes területére.

Dolgozatunk célja a Szilágyság florisztikai-növényföldrajzi jellemzése, ezen belül a kárpáti, erdélyi, dácikus és pannóniai karakter hangsúlyozása.

\section{Anyag és módszer}

Míg jelen dolgozatunkban a kutatott területet Szilágy megye adminisztrativ határai korlátozzák, a különböző - általunk elemzett - endemikus fajok elterjedése jól meghatározható földrajzi egységekre jellemző. A kárpáti endemizmusok expanziója eme hegyláncnak a Dunával érintkező részétől (Kis-Kárpátok) egészen a szerbiai Timok völgyéig tartó szakaszára terjed ki. Az erdélyi fajok elterjedése az Erdélyi-medencére és közvetlen környékére korlátozódik. A dácikus elemek areáljának értelmezése idökőzben változásokon ment át: míg JANKA (1860) ezek alatt az erdélyi endemizmusokat értette, Soó (1942) a KeletiKárpátok és a Balkáni-hegység csak itt élő, közös fajait összegezte. Mi ebbe a csoportba azon endemikus flóraelemeket soroljuk, amelyek a Kárpátok kassai törésvonalától a szerbiai Timok völgyéig fordulnak elő. A pannon fajok az alföldi régió szikeseinek és homokterületeinek, valamint az ezt közvetlenűl szegélyző dombvidékek endemizmusai. Az említett fajok közül néhány, természetes irradiáció nyomán, helyenként a szomszédos területekre is behatolhat (például Moldovába), így ezek a szubendemikus flóraelemek csoportját gazdagítják.

Dolgozatunkban a nomenklaturát a következő szakmunkákra támaszkodva használjuk: Flora Romaniae (SĂvUlESCU 1952-1976), Flora Europaea (TuTin et al. 1964-1980, TuTin et al. 1993) valamint az Euro+Med PlandBase és The Plant List adatbázisok.

A vizsgált herbáriumok akronímjai HoLMGREN et al. (1990) munkáját követik. További gyüjtemények: [CAREI] = Nagykárolyi Municipiumi Múzeum; [JIBOU] = A Zsibói Botanikus Kert gyűjteménye. NtGN = Gavril Negrean jegyzetfüzete.

\section{Enumeráció}

Aconitum moldavicum Hacq. s. l. - Prisznel domb (Culmea Prisnelului), a Rea völgye felett, csúcsközelben (KARÁCSONYI \& NEGREAN 2013). Dióspatak (Vălişoara), 2012. 05. 19., Karácsonyi, idem, 2014. 05. 21., Karácsonyi. Kőfrinkafalva (Frâncenii de Piatră), bükkösben - tömegesen, $47.33948^{\circ} 23.69566^{\circ}$, kb. 410 m, 2015. 06. 02., Karácsonyi \& Negrean. Sztána (Stana) környékén, as. Fagetum silvaticae, 1943 (UJVÁRosı 1947). Flóraelem: kárpáti faj. 
Cardamine glanduligera O. Schwarz (Dentaria glandulosa Waldst. \& Kit.) - Tuszatelke (Tusa) S, fennsíkon, ültetett fenyvesben, $47.01469^{\circ} 22.75343^{\circ}$, kb. $763 \mathrm{~m}, 2015.04 .01$., Negrean (NtGN: 22.312) [BUC; I]. Zilah (Zalău), Nádastó, az Északhegy északnyugati lejtője, 510 m, 1941. 05. 14., as. Fagetum silvaticae-praehungaricum, Allium ursinum fácies (BALÁzS 1941). Prisznel magaslat (Culmea Prisnelului) csúcsközelben, a Rea patak völgye felett (KARÁCSONYI \& NEGREAN 2013). Szamosőrmező (Var), 47.24055²3.27916 , kb. 222 m, 2014. 03. 17., Szatmari. Szurduk (Surduc) Szalonnapatak (Solona) felé, Hrăii patak völgye, 2014. 03. 14., Szatmari. Csákigorbó (Gârbou) N, Tótszállás (Brâglez) patak völgye,

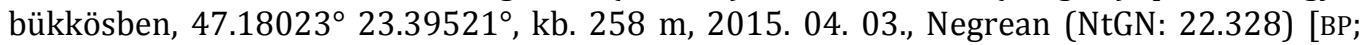
BUC; I]. Oláhfodorháza (Fodora) W, meredek lejtőn bükkösben, $47.26203^{\circ} 23.64968^{\circ}$, kb. 250 m, 2015. 04. 02., Szatmari, Negrean \& Karácsonyi. Huta (Huta) SW, 47.00932 ${ }^{\circ}$, 22.94847 ${ }^{\circ}$ kb. 473 m, 2014. 04. 23., Negrean \& Karácsonyi [CAREI]. Szélesbérc gerince, 650 m, 1941. 06. 16., as. Fagetum silvaticae-praehungaricum, Asperula odorata fácies (BALÁzS 1941). Perjei Magura, 760 m, 1941. 06. 16., as. Fagetum silvaticae-praehungaricum, Asperula odorata fácies (BALÁzS 1941). Perjei Magura (Măgura Priei), 2014. 05. 22., Karácsonyi [CAREI]. Pajk csúcs (Vârful Poicului), Pajk hegy (Dealul Vleșinului), 900 m, 1941. 06. 28., as. Fagetum silvaticae-praehungaricum, Carex sylvatica facies (BALÁzs 1941). Terbete hegy keleti oldalán, 800 m, 1941. 05. 15., as. Fagetum silvaticae-praehungaricum, Aposeris foetida fácies (BALÁzs 1941). Meszes-hegység (Munţii Meseş), Pajk völgye, ültetett fenyvesben, $46.97477^{\circ} 22.93611^{\circ}$, kb. $630 \mathrm{~m}, 2013.05 .10$., Negrean (NtGN: 19.467) [JIBOU]. Huta (Huta) NE - Kásapatak (Bogdana) Ny, Meszes-hegység, erdő, 47.02276 $22.96172^{\circ}$, kb. 478 m, 2015. 07. 01., Szatmari. Csömörlő (Ciumărna); Csűrfalva (Cliţ); Bagolyfalva (Hurez); Boronamező (Poniţa); Felsőkecel (Meseşenii de Sus); Plopis-hegység (Munţii Plopiş); Sztána (Stana) (MorARIU et al. 1984). Sztána (Stana) környéke, as. Fagetum silvaticae (UJVÁROSI 1947). Sztána (Stana), Riszeg-tető, bükkösben ritka (PÉNTEK \& SzABó 1985). Flóraelem: kárpáti-(ÉNy)balkáni.

Centaurea pugioniformis Nyár. - Zilah (Zalău), 370 m, as. Trifolio-Agrimonietum Th. Müller (COLDEA \& POP 1994). Flóraelem: dácikus-erdélyi faj.

Centaurea sadleriana Janka (Centaurea scabiosa L. subsp. sadleriana (Janka) Asch. \& Graebn.) - Kárásztelek (Carastelec), 2009. 07. 25., Karácsonyi; 08. 06., Karácsonyi (KARÁCSONYI \& NEGREAN 2013). Kárásztelek (Carastelec), erdő mellett Krasznahidvég (Măieriște) felé, 2013. 08. 06., Karácsonyi, idem 2014, comm. Karácsonyi, fotó Bartók Attila. Flóraelem: pannon faj.

Cephalaria radiata Griseb. \& Schenk - Zsibó (Jibou) Botanikus Kert körzetében spontán, 2013 (CĂPRAR \& SZATMARI 2014). Vármező (Buciumi) W, 2014. 05. 22., Karácsonyi. Meszesszentgyörgy (Sângeorgiu de Meseş) NW, Măgura domb, felszíni (gipsz) sziklákon, $47.04612^{\circ} 22.99147^{\circ}, \mathrm{kb} .430 \mathrm{~m}, 2014.06 .27 .$, Negrean. Almásbalázsháza (Bălan) (KARÁCSONYI \& NEGREAN 2013), 2013. 07. 07., Karácsonyi [CAREI]. Hidalmás (Hida) (KARÁCSONYI \& NEGREAN 2013). Topaszentkirály (Sâncraiu Almaşului) E, beerdősülő réteken, vékony talajrétegen, $46.95341^{\circ} 23.36825^{\circ}$, kb. $378 \mathrm{~m}, 2014$. 04. 26., Negrean (NtGN: 21.794) [BUC]. Ugróc (Ugruţiu), 2014. 05. 14., Karácsonyi [CAREI]. Vásártelke (Stoboru), 2014. 05. 20., Karácsonyi. Vásártelke (Stoboru) NNE, Bozolnic völgye, füves domboldalakon, $46.94281^{\circ} 23.29073^{\circ}$, kb. 330 m, 2014. 04. 26., Negrean (NtGN: 21.788) [JIBOU]. Ugróc (Ugruţiu) NW, Ugróc patak völgye, igen meredek domboldalakon, Valea Ugruţiu, 47.01922 ${ }^{\circ} 23.36171^{\circ}$, kb. 329 m, 2014. 04. 24., Negrean \& Szatmari (NtGN: 21.803) [BUC; JIBOU]. Almástamási (Tămaşa), 2013. 07. 09., Karácsonyi [CAREI]. Almástamási (Tămaşa) SE, Dâncu völgye, mészkövön, 46.94834²3.19252º kb. 378 m, 2013. 07. 09., Negrean (NtGN 19.665) [JIBOU]. Farnas (Sfâraş) S, gipszes domboldalakon, 46.89931 23.09856, kb. 364 m, 2013. 05. 10., Negrean (NtGN: 19.492) [JIBOU]. Zsobok (Jebucu) N, „Pad”, 2014. 06. 28., Karácsonyi. Zsobok (Jebucu), a sztánai (Stana) állomás felett: 
Keresztdomb és Riszeg-tető, 1943, as. Carici humilis-Brachypodietum pinnati Soó (UJVÁRosi 1947). Erdélyi elterjedési térképe: Soó (1942). Flóraelem: erdélyi faj.

Cirsium furiens Griseb. \& Schenk - „Szilágy” (Sălaj) (TATÁR 1939). Transsilvanicum, Praepannonicum (Cott. Szilágy ...)" (Soó 1942). Szilágyballa (Borla) (KARÁCSONYI \& NEGREAN 2013). Lencsmér (Leşmir), 2014. 09. 17., Karácsonyi [CAREI]. Haraklány (Hereclean), 2013. 08. 06., Karácsonyi [CAREI]. Halmosd (Halmăşd) (COLDEA 1972, KARÁCSONYI \& NEGREAN 2013). Topaszentkirály (Sâncraiu-Almaşului) E, beerdősülő réteken, vékony talajrétegen, $46.95313^{\circ} 23.37946^{\circ}$, kb. 428 m, 2014. 04. 26., Negrean (NtGN: 21.797) [BUC; JIBOU]. Sztána (Stana), Zsobok (Jebucu) (PÉNTEK \& SzaBó 1985). „Csigadomb - Szent Pál-tető (Nyárády)” (Soó 1942). „BALÁzS meszeshegységi adatai (AGH IV: 176) részben bizonytalanok, cf. Soó (AGH IV: 350)" (Soó 1942). Erdélyi elterjedési térképe: Soó (1942). Flóraelem: pannondácikus faj.

Crocus banaticus J. Gay (Crocus iridiflorus Heuffel ex Reichenb.) - Inó (Inău) SSW, erdő, $47.37168^{\circ} 23.26704^{\circ}, k b .206$ m, 2014. 04. 24., Negrean. Szamosszéplak (Aluniş), $47.37083^{\circ} 23.26722^{\circ}$, kb. $196 \mathrm{~m}, 2014.04 .25 .$, Szatmari. Gyulaszeg (Ciula) (KARÁCSONYI \& NEGREAN 2013). Zilah-Vártelek (Ortelec) E, Vártelek völgye, bükkösben, 47.21120 23.12707, kb. 299 m, 2014. 04. 22., Negrean (NtGN: 21.721) [BUC]. Kiskeresztbánya (Teştioara) E, a Sphagnum-os lápoknál, $47.25833^{\circ} 23.43361^{\circ}$, kb. $336 \mathrm{~m}, 2013.09 .17 .$, Szatmari \& Negrean. Pórkerec (Purcăreț), Pórkerec patak völgye (KARÁCSONYI \& NEGREAN 2013). Dióspatak (Vălişoara) S, 2013. 09. 20., Negrean. Meszes-hegység (Munții Meseș) Perjei Magura (Măgura Priei), Tisztásgerinc, a Mezőpatak völgyében, 820 m, 1941. 09. 26., as. Fagetum silvaticae-praehungaricum, Oxalis acetosella fácies (BALÁZs 1941). A Ponorel (Ponorel) hegy csúcsán, réteken Tuszatelke (Tusa) felé, 1871. 09. (FeichTinger 1875). „Meszes-hegység (Munţii Meseş) a Perjei Magurán (Zilah rajon)” (ProdAn \& NYÁRÁdY 1966). Huta (Huta) SE, Egregy völgye (Valea Agrijului), bükkösben, $46.99326^{\circ} 22.92841^{\circ}$, kb. 574 m magasságon, 2014. 04. 23., Negrean. Csákigorbó (Gârbou) N, Tóthszállás (Brâglez) patak völgye, erdőben, $47.18023^{\circ} 23.39521^{\circ}$, kb. 258 m magasságon, 2015. 04. 03., Negrean.

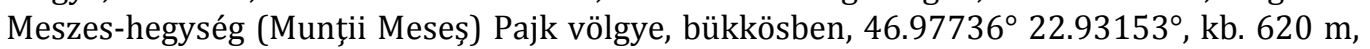
2013. 05. 10., Negrean (NtGN: 19.443) [JIBOU]. Flóraelem: dácikus-balkáni (ÉNy) faj.

Galium abaujense Borbás - Tasnádi-dombvidék (Dealurile Tăşnadului), csertölgyesekben: Kárásztelek (Carastelec) és Kémer (Camăr). - Erről a területről korábban gyüjtött példányokat a nemzetség monográfusa Fr. Krendl (Bécs) határozta meg (KARÁcsonYI 2011). Szurduk (Surduc) SW, dombon: a Jósika család kriptájának közelében, 47.24990 ${ }^{\circ}$ 23.34147º, kb. 198 m, 2015. 05. 06., Negrean. Zsibó (Jibou) NW, erdőben, 47.27251 23.24227\% , kb. 329 m, 2014. 05. 20., Karácsonyi. Dióspatak (Vălişoara) NE, Prisznel dombvonulat, Pleska (Pleşca) csúcs, erdőben, 47.39176² 23.41017º, kb. 622 m, 2014. 05. 21., Negrean (N: 22.072) [BUC; I]. Blenkmező (Poiana Blenchii) N, Poiana patak völgye, Báboly szoros, $47.32093^{\circ} 23.74671^{\circ}$, kb. 291 m, 2015. 06. 02., Negrean. Flóraelem: kárpátipannon faj.

Helleborus purpurascens Waldst. \& Kit. - Csákigorbói-dombvidék (Dealurile Şimişna Gârbou) (KARÁCSONYI \& NEGREAN 2013). Szamosdebrecen (Vădurele), falu közelében, 2013. 05. 11., Karácsonyi [CAREI]. Dióspatak (Vălişoara) N, Prisnel domb, fennsíkon, $47.40416^{\circ}$ 23.43222 ${ }^{\circ}$, kb. 623 m, 2013. 09. 20., Karácsonyi \& Negrean. Kőfrinkfalva (Frâncenii de Piatră), bükkösben, $47.33948^{\circ} 23.69566^{\circ}, 2015$. 06. 02., Karácsonyi \& Negrean. Csákigorbói-dombvidék, Paptelke (Popteleac) W, Ungurului völgye, Băltişeni erdő, $430 \mathrm{~m}$, 1986. 07. 24., as. Carpino-Fagetum Paucă (CoLDEA et al. 1987). Meszes-hegység (Munții Meseş) (KARÁCSONYI \& NEGREAN 2013). Meszesszentgyörgy (Sângeorgiu de Meseş) NW, Magura (Măgura) domb, völgy meredek falak alatt, szurdok, $47.04661^{\circ} 22.98427^{\circ}$, kb. 451 m, 2014. 06. 27., Negrean. Perjei Magura (Măgura Priei) csúcs alatt (FEICHTinger 1875). Meszes-hegység (Munţii Meseş): Medvehegy, Perjei Magura csúcsok, Felsőnyárló (Stâna) 
(NYÁRÁDY 1953). Meszesszentgyörgy (Sângeorgiu de Meseş), 2014. 06. 27., Karácsonyi [CAREI]. Hidalmás (Hida), 2012. 05. 13., Karácsonyi [CAREI]. Topaszentkirály (SâncraiuAlmaşului) ESE, erdőszélen, $46.94870^{\circ} 23.37869^{\circ}$, kb. 406 m, 2014. 04. 26., Szatmari \& Negrean. „Erdőkben, cserjésekben, réteken ... Sztána (Stana)” (FrEYN 1877). Infraspecifikus taxon: forma baumgartenii (Kov.) Nyár. - „Meszes-hegység (Munţii Meseş): Perjei Magura (Măgura Priei), Medvehegy (Osoiul Ursului) csúcs" (NYÁRÁDY 1953). Flóraelem: kárpáti faj.

Jurinea transylvanica (Spreng.) Simonk. [Jurinea simonkaiana Nyár.; Jurinea mollis subsp. transsilvanica (Spreng.) Hayek] - „Szamos-fennsík (Podişul Someşan), Almás-Egregymedence, 220-500 m, 1971/72, leg. A. T. Szabó; D. Pázmány; E. Chircă (SzaBó 1973, PÁZMÁNY 1973, CHIRCĂ 1974). Vajdaháza (Voivodeni) keleti szegélyén, meredek domboldalon, $47.05278^{\circ} 23.44546^{\circ}$, kb. $345 \mathrm{~m}, 2013.07 .06$., Negrean (NtGN: 19.608) [BUC; CL; JIBOU]. Vajdaháza (Voivodeni), 2013. 07. 06., Karácsonyi. Almáshida (Hida) ESE, Ugróc völgye, száraz füves helyen, $47.03231^{\circ} 23.35005^{\circ}$, kb. $359 \mathrm{~m}, 2013.07 .07 .$, Negrean (N 19.711) [JIBOU]. Almástamási (Tămaşa), 2013. 07. 09., Karácsonyi [CAREI]. Kalotaszegen (Zona Călata) (KARÁCsonYI \& NEGREAN 2013, apud PÉNTEK \& SZABó 1985). Farnas (Sfăraş) Sztána (Stana) felé, 2013. 05. 10., Karácsonyi [CAREI]. Zsobok (Jebucu) N, meredek domboldalakon Artemisia alba-val, 46.89431 $23.10483^{\circ}$, kb. 390 m, 2014. 06. 28., Karácsonyi \& Negrean. Sztána (Stana), állomás felet Kereszthegy és Riszeg-tető, as. Carici humilis-Brachypodietum pinnati Soó (Ujvárosi 1947). Zsobok (Jebucu) D, Riszeg-tető, lejtő NW, $46.85570^{\circ} 23.10419^{\circ}$, kb. $681 \mathrm{~m}, 2014.06 .28$. , Negrean. Tóthtelke (Gălășeni) N, gipsz és mészkőfejtő, $46.90623^{\circ} 23.18530^{\circ}$, kb. $368 \mathrm{~m}, 2014$. 05. 23., Karácsonyi \& Negrean. Erdélyi-medence (Bazinul Transilvaniei), csak kivételesen jelentkezik a Kárpátkoszorú ellenkező (keleti vagy déli) oldalán, mint például Sárvulkánok (Vulcanii Noroioşi) vidékén, valamint ritkán a pannon flóratartományban is. Elterjedési térképe: Soó (1942). Flóraelem: dácikus (erdélyi) faj.

Melampyrum barbatum Waldst. \& Kit. ex. Willd subsp. barbatum - „? Szilágy” (TATÁR 1939). Dióspatak (Vălişoara), Prisznel domb, 2014. 05. 21., Karácsonyi [CAREI]. Réz-hegység (Plopiş) (FEICHTINGER 1895). Vármező (Buciumi) W, a Kraszna völgye felé eső nyeregben, 2014. 05. 23., Karácsonyi [CAREI]. Meszesszentgyörgy (Sângeorgiu de Meseş) W, dombok egykori teraszain, $47.04658^{\circ} 22.99091^{\circ}$. A törzsalak európai endémizmus: Ausztriától keletre Romániáig és északnyugat Jugoszláviáig (TATÁr 1939, Soó \& WEBB 1972). Flóraelem: pannon - géta faj.

Onosma pseudoarenaria Schur subsp. pseudoarenaria (Onosma arenaria Waldst. \& Kit. subsp. pseudoarenaria (Schur) Jáv.) - Ugróc (Ugruțiu), $47.01922^{\circ} 23.36171^{\circ}$, kb. $329 \mathrm{~m}$, 2014. 04. 26., Karácsonyi \& Negrean [CAREI]. Farnas (Sfăraş) Sztána (Stana) felé, 2013. 05. 10., Karácsonyi [CAREI]. Zsobok (Jebucu) és Farnas (Sfăraş) között, a „Pad” nevű helyen, 1974. 08. 13., as. Gypsophilo-Brachypodietum pinnati agropyrosum truncati A. T. Szabó (SZABó 1983). Almástamási (Tămaşa): meredek partfalakon, $46.95053^{\circ} 23.17525^{\circ}$, kb. 395 m, 2014. 05. 20., Negrean. Megjegyzés: ŞuTEu et al. (2012) szerint: izolált populációk, csekély egyedszámmal; igen veszélyeztetett; védelmet igényelnek. Térkép: ŞUTEU et al. (2012). Erdélyi-medence (Bazinul Transilvaniei). Flóraelem: erdélyi faj.

Phyteuma tetramerum Schur - Perjei Magura (Măgura Priei), a Mező-patak völgyében a Tisztás gerinc felé, $880 \mathrm{~m}$ magasságon,1941. 06. 17., as. Cardaminetum amarae (BALÁzS 1941, KARÁCSONYI \& NEGREAN 2013). Csűrfalva (Cliţ) DDK, mellékpatak völgyében, 47.29134 23.43055, kb. 222 m, 2014. 05. 24., Szatmari \& Karácsonyi, leg. G. Negrean. Meszes-hegység (Munţii Meseş): Pajk völgye, a Pajk csúcs (Vlesin) északi oldalán, $550 \mathrm{~m}$, 1941. 06. 28., as. Festucetum rubrae (BALÁzs 1941). Meszes-hegység, Perjei Magura, Tisztásgerinc, 900 m, 1941. 06. 17., as. Deschampsietum flexuosae (BALÁzs 1941). Sztána (Stana), Pajk csúcs (Vlesin) a Meszes-hegységben, Perjei Magura (GHIŞA 1964). Tuszatelke (Tusa), 2015. 06. 30., Karácsonyi. Flóraelem: dácikus faj. 
Rhinanthus wagneri Degen (Rhinanthus rumelicus Velen. subsp. wagneri (Degen) Bjelčic) Ököritó (Sălăjeni), 47.32722 $22.89111^{\circ}$, kb. 240 m, 2013. 06. 26., Szatmari. Selymesilosva (Ilişua), 2013. 05. 23., Karácsonyi [CAREI]. Szilágysziget (Sighetul Silvaniei), 2013. 06. 26., Karácsonyi [CAREI]. Szamosszéplak (Aluniş), 2013. 06. 21., Karácsonyi [CAREI]. Dióspatak (Vălişoara) É, Prisznel domb, 47.38916² 23.40361', kb. 626 m, 2014. 05. 21., Negrean (N: 22.064) [BUC]. Sztána (Stana) \& Zsobok (Jebucu) (MolnÁR et al. 2014). Flóraelem: dácikuspannon-(észak)balkáni faj.

Seseli gracile Waldst. \& Kit. - As. Seseli gracile-Festucetum pallentis: Blenkmező (Poiana Blenchii) Báboly-szoros (Cheile Babii) (KARÁCSONYI \& NEGREAN 2013). „Sztána (Stana) környéken", as. Gypsophilo-Brachypodietum pinnati stiposum capillatae A. T. Szabó (SzABó 1983). A sztánai (Stana) állomás felett a Keresztdombon és Riszeg-tetőn, as. Carici humilisBrachypodietum pinnati Soó (UJVÁrosi 1947). „Zsobok-Pad” (Jebucu-Pad), 2014. 05. 22., Karácsonyi. Zsobok (Jebucu) S, Riszeg-tető, D felé, tisztáson, 46.85385²3.10999, kb. 712 m, 2014. 06. 28., Negrean. Flóraelem: dácikus-balkáni (északnyugat); vagy dácikus subendemikus faj.

Sesleria heufleriana Schur subsp. heufleriana - Kecskés (Cozla) NW, mészplató, a meredek és beerdősült mészfalak peremén, $47.35879^{\circ} 23.37275^{\circ}$, kb. 553 m, 2015. 07. 07., Negrean. Dióspatak (Vălişoara), Prisznel domb (KARÁCSONYI \& NEGREAN 2013), 2014. 04. 22., Karácsonyi, idem, Pleska (Pleşca) csúcs, $47.39178^{\circ} 23.40934^{\circ}$, kb. 621 m, 2014. 04. 22., Negrean (NtGN: 21.735) [BUC; JIBOU]. Csűrfalva (Cliţ) Csűrfalvi sziklák (Stanii Cliţului) meredek falain, füves párkányokon, $47.28808^{\circ} 23.41850^{\circ}, \mathrm{kb} .243 \mathrm{~m}, 2013$. 05. 09., Negrean (NtGN: 19.784) [JIBOU]. Csűrfalva (Cliţ) SSE, Csűrfalvi (Cliţ) patak völgye, erdei út mellett, $47.28680^{\circ} 23.43544^{\circ}$, kb. 236 m, 2014. 06. 25., Negrean \& Szatmari. Tuszatelke (Tusa) Ponor, Piatra Ciutii, 2014. 10. 02., Karácsonyi [CAREI]. Farnas (Sfăraş), $46.89777^{\circ}$

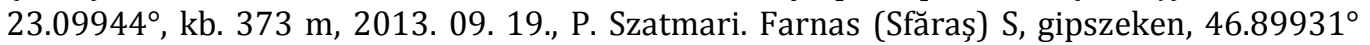
23.09856 ${ }^{\circ}$, kb. 364 m, 2013. 05. 10., Negrean (NtGN: 19.495) [JIBOU]. Farnas (Sfăraş) Zsobok (Jebucu), 2014. 04. 23., Karácsonyi [CAREI]. Sztána (Stana), Riszeg-tető, nyugati lejtőn, as. Seslerietum heuflerianae Soó (kissebb populáció) (UJVÁRosI 1947). Sztána (Stana), állomás felett a Riszeg-tető nyergében, as. Carici humilis-Brachypodietum pinnati Soó, kezdeti stádiumban lévő fáciest alkot (UJVÁrosi 1947: 12). Zsobok (Jebucu) S, Riszegtető, északnyugati lejtő tisztásain, $46.85570^{\circ} 23.10419^{\circ}$, kb. $681 \mathrm{~m}, 2014$. 06. 28., G. Negrean. Zsobok (Jebucu), Pénzesdomb, Padoldal: Sztána (Stana) Riszeg-tető (MolNÁR et al. 2014). Flóraelem: kárpáti faj.

Sorbus danubialis (Jáv.) Kárpáti (Sorbus cretica (Lindl.) Fitsch \& Rech. forma danubialis Jáv.; Sorbus cretica subsp. danubialis (Jáv.) Jáv.) - Kecskés (Cozla) W, a mészkőplató szinte teljesen függőleges, beerdősült falain, $47.35879^{\circ} 23.37275^{\circ}$, kb. 553 m, 2015. 07. 02., Negrean, Karácsonyi \& Szatmari, idem, 2015. 08. 05., C. Karácsonyi \& V. Kerényi-Nagy, det. Németh Csaba [BP; CAREI]. Flóraelem: kárpáti(Jura).

Symphytum cordatum Waldst. \& Kit. - Prisznel dombvonulat (Culmea Prisnelului) a Rea patak felett csúcsközelben (KARÁCSONYI \& NEGREAN 2013). Szalonnapatak (Solona) Hrăii patak völgye, $47.27572^{\circ} 23.41519^{\circ}$, kb 266 m, 2015. 04. 02., Szatmari. Csűrfalva (Cliţ) SW, Csürfalvi patak völgye, $47.28082^{\circ} 23.45382^{\circ}, \mathrm{kb} .257 \mathrm{~m}, 2015$. 06. 02., Negrean. Oláhfodorháza (Fodora), bükkös meredek partfalon, $47.26203^{\circ} 23.64968^{\circ}, \mathrm{kb} .250 \mathrm{~m}$, 2015. 04. 02., Szatmari. Tuszatelke (Tusa), Boului patak völgye, kb. 560 m, as. StellarioAlnetum glutinosae Lohm., 1968. 06. 28. (ColDEA 1984). Halmosd (Halmăşd) patak völgye, 2015. 04. 26., Karácsonyi. Ördögkút (Treznea), mély völgy a bükkösben, 2015. 06. 02.9, Karácsonyi. „Meszes-hegység (Munţii Meseş), Boronamező (Poniţa), patak völgye, Terebete hegy, Cătălu mellet (Zilah rajon)" (GuşulEAC 1960). Meszes hegység (Munţii Meseş) Szélesbérc, kb. 650 m, 1941. 06. 16., as. Fagetum silvaticae-praehungaricum, Asperula odorata fácies (BALÁzs 1941). Perjei Magura (Măgura Priei), kb. 760 m, 1941. 06. 16., as. 
Fagetum silvaticae-praehungaricum, Asperula odorata fácies (BALÁzs 1941). Kásapatak (Bogdana) NY, Meszes-hegység a gerinc alatt, W, bükkösben, 2015. 07. 01., Karácsonyi. Pajk csúcs (Vlesinului), kb. 900 m, 1941. 06. 28., as. Fagetum silvaticae-praehungaricum, Carex sylvatica fácies (BALÁzs 1941). Terbete hegy keleti oldal, kb. $800 \mathrm{~m}, 1941.05 .15$. , as. Fagetum silvaticae-praehungaricum, Aposeris foetida fácies (BALÁzs 1941). Flóraelem: kárpáti faj.

Thymus comosus Heuffel ex Griseb. \& Schenk - Dióspatak (Vălişoara), Prisznel domb, 2014. 05. 21., Karácsonyi [CAREI]. Blenkmező (Poiana Blenchii), Báboly szoros (HodișAN \& ŞUTEU 1979), 2013. 05. 07., Karácsonyi [CAREI] (KARÁCSONYI \& NEGREAN 2013). Kalotaszeg (Zona Călata) (KARÁCSONYI \& NEGREAN 2013, apud PÉNTEK \& SZABó 1985). Farnas (Sfăraş) S, gipszes domboldalon, $46.94828^{\circ} 23.09870^{\circ}$, kb $366 \mathrm{~m}, 2013.09 .19$., Negrean (NtGN 20.222) [BUC], idem, Szatmari. Zsobok (Jebucu) és Farnas (Sfăraș) között a „Pad” nevű helyen, 1974. 08. 13., as. Gypsophilo-Brachypodietum pinnati agropyrosum truncati A. T. Szabó (SzABó 1983). Sztánai (Stana) állomás felett a, Keresztdombon és a Riszeg-tetőn, as. Carici humilisBrachypodietum pinnati Soó (UJVÁRosi 1947). Flóraelem: dácikus faj.

Thymus dacicus Borbás - „Várad tartomány, Meszes-hegység (Muntele Mezeş)” (ProdAN 1954). Meszes-hegység (Munţii Meseș) (GuşulEaC 1961). Infraspecifikus taxon: forma parviflorus Opiz - „Pajk völgye (Valea Poicului) Meszes-hegység (Munţii Meseş) (Bánffyhunyad /Huedin/ rajon)" (GuşulEAC 1961). Flóraelem: transilvano (erdélyi)dácikus.

Viola jooi Janka - Dióspatak (Vălişoara), Prisznel domb, $47.38638^{\circ} 23.40055^{\circ}$, kb. $620 \mathrm{~m}$, 2013. 09. 20., Szatmari, idem, Negrean (NtGN: 20.242) [BUC]. (KARÁCSONYI \& NEGREAN 2013), 2014. 05. 21., Karácsonyi. Meszesszentgyörgy (Sângeorgiu de Meseş) WNW, Magura domb, szurdokvölgy meredek falakkal, $47.04661^{\circ} 22.98427^{\circ}$, kb. $451 \mathrm{~m}, 2014$. 06. 27., idem, 2015. 05. 05., Negrean. Kalotaszeg (Zona Călata) - Alszeg (KARÁCSONYI \& NEGREAN 2013, apud PÉNTEK \& SzABó 1985). Farnas (Sfăraş), Zsobok (Jebucu) (PÉnTeK \& SzABó 1985). Sztánai (Stana) állomás felett. Keresztdomb és Riszeg-tető, as. Carici humilis-Brachypodietum pinnati Soó (UJVÁRoSI 1947). „Sztána (Stana), Riszeg-tető, nyugati irányban, as. Seslerietum heuflerianae Soó (fajszegény populációk)" (UJVÁRoSI 1947). Sztána (Stana) a bánya felett, ritka (MolNÁR et al. 2014). Flóraelem: dácikus faj.

Waldsteinia geoides Willd. - Meszesszentgyörgy (Sângeorgiu de Meseș), 2014. 06. 27., comm. Negrean, leg. Karácsonyi [CAREI], idem, Magura (Măgura) domb, szakadék, meredek falakon, $47.04661^{\circ} 22.98427^{\circ}$, kb. $451 \mathrm{~m}, 2014.06 .27$., Negrean \& Szatmari. Flóraelem: kárpáti-(észak)balkáni faj.

\section{Értékelés}

A hegyvidékeken jelentkező kárpáti fajok (például Helleborus purpurascens Waldst. \& Kit., Symphytum cordatum Waldst. \& Kit., Sesleria heufleriana Schur) közül, az Aconitum moldavicum Hacq. itteni előfodulásának körülményei meglepőek. A kárpáti sisakvirág ugyanis pontosan a hegyvidékről hiányzik, és csupán a Szilágyság keleti részének dombvidékén található. Ez mindenképp arra utal, hogy ide a Keleti-Kárpátokból telepedett be. Viszont ennek függvényében, igen különös a Nyugati-dombvidéken, a Szatmár megyei Érszakácsiban (Săcăşeni), kb. 180 m magasságon azonosított izolált lelőhelye (KARÁCSONYI 2011). A kárpáti-balkáni elemek közül a Cardamine glanduligera O. Schwarz a Szilágyságban helyenként 250 m magasság alá is leereszkedik, míg a Waldsteinia geoides Willd. a kutatott területen csak kivételesen fordul elő.

$\mathrm{Az}$ erdélyi fajok közül a Cephalaria radiata Griseb. \& Schenk és az Onosma pseudoarenaria Schur itteni elterjedése csak a Kalotaszeg (Călata) és az Almás (Almaş) patak völgyi termőhelyekre korlátozódik. 
A dácikus fajok egy része [Jurinea transylvanica (Spreng.) Simonk., Thymus comosus Heuffel ex Griseb. \& Schenk, Viola jooi Janka] főleg csak a Szilágyság mészkövein jelentkezik, míg a dácikus-balkáni jellegű (e terület több régiójában elterjedt) Crocus banaticus J. Gay az itteni gyertyánosokban és bükkösökben helyenként nem ritka.

A pannon endemizmusok közül a Centaurea sadleriana Janka-t itt csak egyetlen lelőhelyen azonosítottuk, ellenben a dácikus-pannon flóraelemek közül a Cirsium furiens Griseb. \& Schenk a szilágysági dombvidékeken több termőhelyet benépesít. Az e csoporthoz tartozó (és a felsorolásunkban nem szereplő) Dianthus pontederae A. Kern. a kutatott terület nyugati részében nem ritka.

A különböző földrajzi eredetű endemikus fajok jelenléte különös színfoltja a Szilágyság flórájának, amelyek jelentős mértékben hozzájárulnak ennek változatosságához.

\section{Irodalom}

BALÁzs F. (1941): Vegetációtanulmányok a Meszes hegységben. Vegetationstudien im Meszesgebirge. Acta Geobotanica Hungarica 4: 119-182.

CĂPRAR M. \& SZATMARI P.-M. (2014): Semina plantarum spontanearum a Hortus Botanicus Jibou in anno 2013 lecta. - Index Seminum, Grădina Botanică Jibou 40: 32-36/33-37.

CHIRCĂ E. (1974): Semina plantarum spontanearum anno 1973, in Transilvania lecta. - Index Seminum, Hortus Agrobotanicus Instituti Agronomici Cluj, 1973: 3-25.

ColdeA G. (1971): Diagrama sporo-polinică a mlaştinii de la Băile Iaz (Munţii Plopiş) [Diagramme sporo-polliniques du marais de Băile Iaz (Monts Plopiş)]. - Studii şi Cercetări de Biologie, seria Botanică 23: 405-408 + 1 Plansa.

ColdeA G. (1972): Flora și vegetaţia Munţilor Plopiş. Teză de doctorat. Universitatea Babeş-Bolyai, ClujNapoca. 262 pp. $31+$ fig.

ColDEA G. (1984): Vegetația lemnoasă de luncă din zona Munţilor Plopiș [La végétation arboricole de plaine inondable dans les Monts Plopiş]. - Acta Mvsei porolissensis (Zalău) 8: 565-570.

ColdeA G. \& PoP A. (1994): Über die Saumgesellschaften (Trifolio-Geranietea Th. Müller 61) aus Siebenbürgen [On the Transylvanian forest-border vegetation (Trifolio-Geranietea Th. Müller 61)] [Sur la végétation de lisière (Trifolio-Geranietea Th. Müller 61) de Transylvanie]. (Siebenbürgische Archiv 30). Naturwissenschaftliche Forschungen über Siebenbürgens 5: 63-76.

Coldea G., Täuber F., Plămadă E., Pop A., BarTóK E. \& Munteanu D. (1987): Cercetări biocenologice în ecosistemele forestiere din dealurile Sălajului şi Gîrboului [Biozönologische Forschungen in den Waldökosystemen der Sălajului und Gîrboului Hügeln] [Biocenotic researches in forest ecosystems from the Sălajului and Gîrboului hills]. - Acta Musei porolissensis, Muzeul de Istorie şi Artă din Zalău 11: 479-492.

FEICHTinger S. (1875): Krasznamegye és környéke Flórájáról [Flora des Comitates Kraszna und Umgebung]. - Mathematikai és Természettudományi Közlemények [1871] 9: 55-115.

FREYN J. (1877): Az 1871-1875 évben Magyarország keleti részében gyűjtött növények jegyzéke. Mathematikai és Természettudományi Közlemények [1875-1876] 13: 75-130.

GHIŞA E. (1964): Phyteuma L. - In: SăvulEscu T. (ed.), Flora României [Flora Romaniae]. Vol. 9. București, pp. 132-139.

Gușuleac M. (1960): Symphytum L. - In: SĂvulescu T. (ed.), Flora României [Flora Romaniae]. Vol. 7. București, pp. 275-286+644.

Gușuleac M. (1961): Thymus L. - In: Săvulescu T. (ed.), Flora României [Flora Romaniae]. Vol. 8. Editura Academiei Române, București, pp. 301-334 + 688-689.

HoDIŞAN I. \& ŞUTEU Ş. (1979): Contribuţii la cunoaşterea vegetaţiei din Cheile Babii (jud. Sălaj) [Beiträge zur Kenntnis der Vegetation aus dem Babii-Klamm und Umgebung (Kreis Sălaj)]. - Studia Universitatis Babeş-Bolyai, Biologia 24: 8-17.

Holmgren P. K., Holmgren N. H. \& BARnetT L. C. (1990): Index Herbariorum, Part I: The Herbaria of the World. 8th ed. - Regnum Vegetabile 120: 1-693. http://sciweb.nybg.org-/science2/IndexHerbariorum.asp

JANKA V. (1860): Adnotationes in plantas dacicas nonnullasque alias europaeas. - Linnaea [1859-1860] 30: 549-622. 
KARÁCSONYI C. (2011): Flora și vegetația dealurilor Tăşnadului şi a colinelor marginale [Flora und Vegetation des Trestenburger Hügellandes und seine Umgebung] [A Tasnádi-dombvidék és környéke flórája és vegetetációja]. - „Vasile Goldiş” University Press, Arad 368 pp.

KARÁCSONYI K. \& NEGREAN G. (2013): A szilágysági növényvilág jellegének vizsgálata [Study on the characteristics of the flora and vegetation in the area of Szilágyság (Sălaj)] [Studiu asupra caracterului covorului vegetal al ținutului Sălajului]. - Kanitzia 20: 101-118.

Molnár Cs., Bódis J., Óvári M., RAKSÁnYi Zs., Bró É., Gerner G., NAGY T., Molnár K. \& Molnár Zs. (2014): Sztána és Zsobok (Kalotaszeg) flórája. - Kitaibelia 19: 114-132.

Morariu I., DAnciu M. \& KovÁCS A. (1984): Corologia speciei Cardamine glanduligera O. Schwarz (Dentaria glandulosa W. et K.) în România. - Studii şi Cercetări de Biologie, seria Biologie Vegetală 36: 35-41.

NyÁRÁDy A. (1953): Helleborus L. - In: SĂvulescu T. (ed.), Flora României [Flora Romaniae]. Vol. 2. Editura Academiei Române, București, pp. 423-430 + 675 .

NyÁrÁdy A., PÁzmány D., Jula F., Chircă E. \& SzABó A. T. (1976): Wiesen und Wälder aus dem Agrij-Almaş becken. - Notulae Botanicae Horti Agrobotanici [1975-1976] 8: 77-81.

PÁZMÁNY D. (1973): Semina plantarum spontanearum anno 1971, 1972 in regione Transilvania, Depresiunea Agrij-Almaș lecta. - Delectus Seminum, Horti Agrobotanici Clujensis 1971-1972: 3-51.

PÉNTEK J. \& SzABó A. (1985): Ember és növényvilág. Kalotaszeg növényzete és népi növényismerete [Lumea vegetală şi cultura tradiţională în zona Călata]. - Kriterion, București, 368 pp.

ProdAn I. (1954): Contribuții la cunoașterea răspîndirii și sistematicii genului Thymus în Republica Populară Romînă [Contributions à la connaissance de la répartition et de la systematique du genre Thymus dans la République Populaire Roumaine] [К иэучению распространения и ситеатики рода Thymus в PHP]. - Buletin Ştiinţific, Secţia de Ştiințe Biologice, Agronomice, Geologice şi Geografice 6: 301-308.

Prodan I. \& Nyárády E. I. (1966): Crocus L. - In: Săvulescu T. (ed.), Flora României [Flora Romaniae]. Vol. 11. Editura Academiei Române, București, pp. 444-454 + 851 .

Săvulescu T. (ed.) (1952-1976): Flora României [Flora Romaniae]. Vol. 1-13. - Editura Academiei Române, București.

Soó R. (1942): Az Erdélyi Medence endemikus és reliktum növényfajai. Die Endemismen und Reliktarten des Siebenbürgischen Beckens. - Acta Geobotanica Hungarica 5: 141-183.

Soó R. \& WebB D. A. (1972): Melampyrum L. - In: Tutin T. G. et al. (eds), Flora Europaea. Vol. 3. Diapensiaceae to Myoporaceae. - Cambridge University Press, 1-370 pp. + 5 maps 253-257.

SzABó A. T. (1973): Semina plantarum spontanearum anno 1971, 1972 in Transilvania (CJ, SJ) lecta. Delectus Seminum, Institutul Agronomic Cluj 1971-1972: 3-82.

SzABó A. T. (1983): Vegetaţia gipsofilă din sud-vestul Podişului Someşan [Gypsophilous plant communities from the south-west of the Someș plateau]. - Ocrotirea Naturii 27: 103-111.

Şuteu D., BĂCILĂ I., URSU T. \& ColdeA G. (2012): Genetic diversity assessment of the Romanian populations of Onosma pseudoarenaria and Onosma arenaria [Estimarea diversităţii genetice a populaţiilor de Onosma pseudoarenaria şi O. arenaria din România]. - Contribuţii Botanice (ClujNapoca), /ser. II/ 47: 49-57.

TATÁR M. (1939): A pannoniai flóra endemikus fajai [Endemische Arten der pannonischen Florenprovinz]. - Acta Geobotanica Hungarica 2: 63-127.

EuRo+Med PlantBase: The information resource for Euro-Mediterranean plant diversity. (Hozzáférés: 2015. 08. 18.)

The Plant List (2013): Version 1.1. Published on the Internet. (Hozzáférés: 2015. 08. 18.)

Tutin T. G., Burges N. A., Chater A. O., Edmondson J. R., Heywood V. H., Moore D. M., Valentine D. H., Walters S. M. \& Webb D. A. (eds) (1993): Flora Europaea. 2nd ed. Vol. 1. Psilotaceae to Platanaceae. - Cambridge University Press, Cambridge, 581 pp.

Tutin T. G., Heywood V. H., Burges N. A., Moore D. M., Valentine D. H., Walters S. M. \& Webb D. A. (eds) (1964-1980): Flora Europaea. Vols. 1-5. - Cambridge University Press, Cambridge.

UJVÁRosı M. (1947): Növényszociológiai vázlatok Sztána környékéről [Pflanzensoziologische Skizzen aus der Umgebung von Sztána in Siebenbürgen]. - Borbásia 7: 3-27.

Beérkezett / received: 2015. 09. 02. • Elfogadva / accepted: 2015. 10. 11. 